\title{
L'ÉLÉGANTE DE LA RUE LEPIC: A NEW LOOK FOR UNE PASSANTE
}

\author{
Alistair Rolls
}

The Liberation of Paris in 1944 saw the meeting of various currents and counter-currents and resembled that magical endroit où of Boris Vian's novel of 1947, L'Écume des jours, where foaming eddies mark the meeting of rivers and seas, a novel that provides a powerful allegory of this period in the history of the city. Paradoxes emerge, foremost amongst which is the simultaneous veiling and unveiling process that was necessary if the people of Paris were to survive the trauma that had taken over their everyday lives. The unveiling of the truth of les années noires (which took various, and variously unpleasant, forms, including the humiliations of the épuration) went hand-in-hand with a drawing-up of veils designed to filter the excessive light of a liberated future. It was as if the uncertainty of what lay in store could be counter-balanced only by an unburdening, and to a large extent, a reconfiguration, of events past (Frank).

As a psychological phenomenon (Rémond 527), the Liberation has been dressed not only for public consumption but also in the public interest. History and literature provided props to distract and mythologies to which people may cling. Nowhere, though, were these fetishes more appropriately formed than in the renewed interest in female fashion, and when Christian Dior launched his new collection in 1947, it was as if he had quite literally created a garment to take the strain of a new gaze. The New Look became the vehicle for a break-out of mass fetishism. For whilst commentators such as Dominique Veillon have seen in Dior's clothes a triumphant break from the past and a movement towards a brighter future, they embody all that is paradoxical about the era; while, on the one hand, they symbolize a belief in better times, on the other hand, their ample skirts cover more than mere nagging doubts. 1 The New Look reaches backwards as well as forwards, and, furthermore, it is not really 'new' at all. 
The reception of the New Look hinges on a curious balancing act, in which Parisian women are both "real" - further removed, perhaps, from the stereotypes of femininity than they have ever been (Higonnet) - they have, for example, been busily occupying traditionally male roles in the workplace - and the Baudelairean Ideal. The description of women in Paris 1947, who "unconsciously yearned for a change of style" (Veillon 145), must be understood against the framework of this dichotomy of women versus Woman. If we consider Valerie Steele's suggestion that "[i]t was because women longed to look like women again that they adopted the New Look" (270) through this lens, then we have an image of real women - the desiring subjects - aspiring to coincide with the ideal woman, an unattainable valeur. If we take this further, we see that the act of "longing" takes place across this opposition, activating it in the form of an impossible instance of communication. This encounter, between women and Woman, takes the historical moment, via the psychological, to the prose poetic, for it is in the specific poetics of Baudelaire's flânerie that the fetishism of the New Look will be seen to be mapped out.

In poetic terms, aspiration is a movement towards the ethereal realm; it is an objective act of representation, requiring time and space (the time, for example, to retreat to a garret to render artistically one's memory of what was previously present to one). The time taken to move into this objective position of representation leads to the kind of longing described by Elizabeth Wilson ("Invisible,"79) "for 'the world we have lost,"' as a result of which "the urban scene comes to represent," utopia and dystopia simultaneously." As critical subjects, our perception is always haunted by desire and regret; and we who walk the streets of the modern city are always in two places at once. 2

It is within this traumatic and double space that we intend to situate a brief moment in the history of Paris. Our focus, the infamous incident of l'élégante de la rue Lepic, is a graphic illustration of the fragmentary nature of all urban relationships, which tends to eschew the construction of coherent grand narratives. 3 The following description of the incident is taken from Antony Beevor and Artemis Cooper's Paris after the Liberation:

The conspicuous extravagance of Dior's clothes was offensive to those for whom 
the war had meant five years of misery. "People shout ordures at you from vans," wrote Nancy Mitford to Eddy SackvilleWest, "because for some reason it creates class feeling in a way no sables could." Just how offensive was proved by a photographic session organized in March 1947, which was designed to display Dior's clothes in typically Parisian surroundings. Among the obvious settings such as the Eiffel Tower and the Champs-Élysées, someone thought of a street market in Montmartre.

The clothes were dispatched to Montmartre in great wooden packingcases on board a camionette. The models changed into them in the back room of a bar. But when, proud and graceful, the first one walked out into the rue Lepic market, the effect was electric. The street sank into an uneasy silence; and then, with a shriek of outrage, a woman stall-holder hurled herself on the nearest model, shouting insults. Another woman joined her, and together they beat the girl, tore her hair, and tried to pull the clothes off her. The other models beat a hasty retreat into the bar, and in a very short time clothes and models were heading back to the safety of the Avenue Montaigne. (315)

The account given by Alistair Horne differs only in the number of models who suffered at the hands of the scandalized women of Montmartre. The amount of participants matters less to Horne than the establishment of the dichotomy that, for him, is the prime driver of this event: "Once more, it was a clear demonstration of the continued coexistence of two Parises - the rich and the poor" (386). I suggest that the violent reaction of the stall-holders is, indeed, a response made to two Parises. For us, however, these are the real Paris, of the present, historical moment and the Paris of myth: what is experienced is simultaneously an event 
that is taking place in the present and an image that is timeless.

This woman passing by in Paris is, therefore, both a unique instance of worldliness and a poetic image; already double and expressing modernity, she calls to mind one poem in particular: "La rue assourdissante autour de moi hurlait. / Longue, mince, en grand deuil, douleur majestueuse, / Une femme passa, d'une main fastueuse / Soulevant, balançant le feston et l'ourlet; / Agile et noble, avec sa jambe de statue." In "À une passante" Baudelaire (Les Fleurs du mal, 270) does more than develop a poetics of modernity; he creates an Urtext, a template for women passing by, whose hold on the French psyche will henceforth be at its strongest in times of extreme duress. Baudelaire's woman passing by and Dior's model, then, meet at the nexus of history, poetry, and fashion.

It is from this perspective of the multi-layered shock of modernity that we can understand the incident of rue Lepic as being as ineluctable as it must have appeared inappropriate. The clothes themselves are equally perverse, their newness cut as it was from nostalgic cloth. Coco Chanel, for one, saw in their "long, full skirts and tightly corseted waists" a reactionary fashion, "inappropriate for the modern woman" (Wilson, Contradictions, 54-55). It is, of course, through such inappropriateness that modernity expresses itself. Dior's women are dressed both as themselves and as they "yearn to be," both in and out of time. In other words, the constricting corsets and free-flowing skirts embody that stilted conversation between women and Woman.

Fashion itself functions according to a double and paradoxical movement. According to Simmel, the evolution of fashion is first and foremost a step taken by the fashionable away from the crowd, but one that always already heralds a recapturing of the fashionable on the part of the crowd. And as Wilson (Contradictions, 51) notes "Quentin Bell (1947) put his finger on a central paradox of fashionable dress when he described how it is individualistic and conformist simultaneously. We dress to be part of the crowd, yet to stand out from the crowd." It is precisely in this double movement that the follower of fashion can be compared to that other major but elusive figure of modernity, the flâneur. Like Dior's models, he is of his time to the extent that he occupies a specific point in history4; and yet, as Chambers reminds us, he is always, at least partially, out of step. In addition 
to being critically perverse, the flâneur is also double in terms of his literary and historical presence. His lifespan was arguably limited to, or at the very least had its heyday in, a quite specific historical period and place: the nature of walking through Paris's streets altered significantly from the birth of the passages de Paris to the opening up of Haussmann's new boulevards, and whether one considers flânerie to have died or to have been improved with Haussmanization, the flâneur has come to symbolize a hermeneutics of loss. On the other hand, there are those (including the author of this essay), who argue that the flâneur's practice is so entwined with Paris that it necessarily haunts the city's ongoing evolution.5 The critical stance of the flâneur is "a specifically Parisian term" and a term for a specific type of Paris insofar as he represents a hermeneutics of loss and presence. 6

Paris, too, can be configured in terms of this parallel presence and absence. In prose-poetic terms it simultaneously coincides and fails to coincide with itself. It is, in a very tangible way, the national capital, a major metropolis in the north of France, which one can encounter in real time; and yet, at the same time, it has a number of connotations, onto any of which it can only ever be imperfectly mapped ("Paris, city of romance" is an example). As the capital of modernity, it has certainly extended beyond its own geographical parameters, becoming a symbol with universal value. For Michel Covin, Baudelaire's flâneur-poet and Paris, capital of modernity, reflect each other to such an extent that Paris becomes, quite simply, a prose poem. Paris is therefore revealed to be auto-antonymic: both the city that presents itself to us as we walk in its streets (prosaic space) and the city of stereotypes, which we represent when we think of Paris in abstract terms, that is to say from the outside (poetic space). 7 When the ideal of female beauty "steps forth in fashion" onto rue Lepic, it is precisely the tension generated by this polarization of Paris that gives the incident its shock value. 8

The incident of rue Lepic stands as a highly reflexive historical analysis offered as a prose-poetic vignette. While poetically, it articulates Baudelaire's concept of fragmented infinity, in terms of historical inquiry, it is also closely aligned to the approach adopted by Walter Benjamin in the Arcades Project. For Benjamin, the dialectical image, which allows him to tell the story of his own present through a reading of the past, frames the 
particular events of a given time within "what has been from time immemorial" (Arcades, 464). The specificity of any event is not an essential quality inherent to the event itself, however; rather, it is determined as such by the reader, whose own historical circumstances are conferred onto it. For him (464), the historical moment "is manifest, on each occasion, only to a quite specific epoch - namely, the one in which humanity, rubbing its eyes, recognizes just this particular dream image as such. It is at this moment that the historian takes up, with regard to that image, the task of interpretation." Such a comparative approach approximates reader-response theory, which is well-suited to our application of prose poetics to an historical event: it allows us to read in parallel two particular moments of writing (Baudelaire's era, when the Urtext of a woman passing by was produced as work, and 1947, when it is performed as text), and thus, in Benjaminian terms, to telescope the past through the present.

The power of "À une passante" is to cast every instance of a woman passing by against a sky that is always already baleful - this "ciel livide où germe l'ouragan." And yet, it is important not to forget that Baudelaire's poem is itself grounded in an historical moment. If we are able to read the incident of rue Lepic through the prism of prose poetics, it is because we are comparing it with Baudelaire's poem as if we were comparing "a collection of concrete, factual images of urban experience" (BuckMorss 115). As Riffaterre has shown, the most radical aspect of reader-based interpretation lies in its potential for reading against the grain of history, which in this case, suggests the use of the later historical event to reread the earlier poem as an historical artifact.

There is a clear tendency in the history of modern France towards mythologizing. 9 There is, for example, a long tradition of viewing the present moment against a representation of a lost utopia (la vieille France). It is equally possible, however, to punctuate this apparently seamless historical trend with specific instances of great moment. In this case, two psychological phenomena: for Baudelaire, the violence of 1848 and the subsequent Haussmannization of the capital; for the stall-holders of rue Lepic, military defeat, Occupation, Liberation and finally the advent of the Cold War and Americanization.

From this perspective of historical trauma our two 
instances of a woman passing by present themselves as case studies in fetishism. According to Freud's essay of 1927, the revelation of the reality of the world is simultaneously remembered (as knowledge) and disavowed (in order for belief in another narrative to be maintained). The fetish allows the subject to deal with the present through a retelling of the past. Whereas Freud offers the tale of a young boy who is led by the discovery of the true nature of his mother's genitals to erect a screen memory whereby the myth of his mother as phallic is able to coexist with the knowledge of her non-phallic reality, here the shocking state of Paris as presence is passed through a fetishistic lens, tempering this existential truth with a mythology, according to which France is - and always has been - in conformity with the onlooker's desire.

In this way fetishism is intimately linked to modernity; both are a means of performing continuity: between present and past, knowledge and desire.10 It is a perverse continuity, of course, since it relies on a balancing act of two contradictory indeed, mutually exclusive - readings of "truth." In this way, the beautiful woman who appears in the city streets is a fetishistic token, as she screens the reality of the everyday and symbolizes the myth/desire of a poetic Paris coinciding with itself (or prosaic Other) in the present. This is the psychological phenomenon on which Les Petits poèmes en prose is predicated, and its influence underpins literary modernism.11 Baudelaire's festoons and hems become the rose-tinted glasses for reading the past. They prefigure the lamentations of the Surrealists in the twentieth century and have particular resonance again at the close of the Second World War.

During the Occupation, the busts of Marianne symbolizing the French Republic were taken down. Physically and symbolically locked away, Marianne is "found again" during the Liberation. Held aloft, these busts function as symbols of the desire for a phallic patrie and as screen memories blocking out the trauma of the hand-over of power from the Germans to the Allies. This myth of the phallic mother is too much to behold directly. Hence Paul Colin's famous poster of 1944, entitled simply "Libération," which shows Marianne holding her hand up to shield her eyes from the excessive light of the new era (Agulhon and Bonte; Forbes and Kelly). 
The need to temper this Utopian myth and contextualize its poetry in the prose of post-war hardship is expressed in 1945 in the violent and unheroic thrillers of the Serrie Noire and its contemporaries. This new prose poetry offers an oblique (and hence digestible) allegory of French readers' present and recent past.12 No incredible salvation is offered to the reader; instead, as in the prose poems, the noir thriller allows glimpses of eternal Beauty in the dark streets of the real world. Both literary forms depend, then, on a non-synthetic juxtaposition of binary oppositions, be it stereotypical verse motifs and mundane objects or ideas of femininity and double-crossing dames (Rolls, "Throwing").

Inherent in any reading of the stall-holders as poets reacting to the woman passing by or as mythmakers relates is the question of gender. While there is scholarship devoted to the possibility of applying Freud's scheme to a female fetishist, the flâneur remains stubbornly male, with feminist readings tending to diffuse the power of the male gaze (McCallum; Gamman and Makinen). Wilson ("Invisible,"80), for example, sees in the flâneur "a figure to be deconstructed, a shifting projection of angst rather than a solid embodiment of male bourgeois power." And yet, such a reading is predicated on the flâneur's voyeuristic attitude, which for Wilson is a "passive, feminine" form of effacement. As we have seen, his voyeuristic side is only one half of the flâneur's dual nature; his other aspect is his ability to move with the crowd. These two apparently passive behaviors, however, combine to form a positive, and the reason that the incident of rue Lepic makes history is that the female stall-holders are moved to action.13 At the end of a war that has made laborers, machineworkers, and soldiers of women, genders have been unbalanced and working-class women cannot simply gaze on what it means "to look like women again." Their action has the effect of applying their gender reversal to the verse poem, and the result is shockingly prose poetic.

From this perspective, the importance of the vision of Dior's model walking across the street lies in the poetic form of the intertext as much as the clothes she is wearing. For "À une passante" is a verse poem that points allegorically beyond itself. As Elissa Marder notes of Benjamin's reading, it is a poem that "must be read as a negative image, in relief, as it were, through the absence of its central figure - the crowd" (128). The 1947 re- 
enactment sees the reinsertion of the crowd, who, this time, assume the position of the poet-narrator. The reinscription of this previously missing element forces us to read the scene more holistically than Benjamin, who, according to Marder (129), "is consistently less concerned with the figure of the passing woman than with the impact that her passage produces on the one who watches her." Marder (130) is critical of Benjamin's apparent dismissal of the woman as an absence because it suggests that he is overlooking the name "fugitive beauté," which bursts from the poet, and which Baudelaire uses to define modernity in his essay, "Le Peintre de la vie moderne." It is as if the woman passing by overarches the binary of real versus ideal woman; she is not only a glance upwards to the poetic but also the downwards motion of the Ideal sinking into the crowd. Unlike the later prose poems, however, her turbulent conflation of incompatible elements ("la douceur qui fascine et le plaisir qui tue") is read by the poet-narrator as a synthesis, however fleeting and fatal. To this extent the woman's eye (the baleful livid-white sky, in and against which the poet takes his fateful drink) proleptically underpins such illustrations of convulsive beauty as Louis Buñuel's surrealist classic Un Chien andalou (1929), where eyes signal the supreme point, the union of pleasure and death.

If the emphasis of Benjamin's reading is of departure (of the woman) and absence (of the crowd), then the actions of the stall-holders of rue Lepic prevent the synthesis of the opposed motions (the abstraction of the real and the reification of the poetic) and force us towards the fetishistic balancing act of the prose poems. And it is in his prose poetry that Baudelaire the poet responds most obviously to the criticisms leveled against him as a theorist by Benjamin, whose own principles of history are predicated on the interaction and co-dependence of the constant and the fleeting.14 In this way, the act becomes allegorical of the predicament of modern Paris, and the stallholders' longing is to ensure that the Ideal be embedded in history and that the woman not pass by too quickly.

The discussion of whether the stall-holders of rue Lepic can stand as flâneur-poets (despite their apparently doubly unflâneur-like nature as active agents and women) in a prose-poetic translation of "À une passante" into the historical moment leads us back to the question of their potential for fetishism. If their reading of the woman passing by follows Benjamin's, then they 
see in her the figure of a widow and at the same time the "vision of modernity that is permeated by the decay of history," which for Benjamin is also that of the "city [that] becomes visible only when it is seen through the veil of a mourning woman" (Marder 134). We should argue that the stall-holders' actions are fetishistic precisely to the extent that they wish to avoid reading in this echo of mourning dress the allegory of decay that Benjamin reads, for example, in Baudelaire's "Le Cygne."15 By ripping the clothes from the woman passing by, therefore, the stall-holders act perversely: their symbolic unveiling functions, fetishistically, as a veiling. In this scenario, what they are longing for is not "to look like women again" but to rebuild the myth of a Paris that is not in ruins, and which can balance out their knowledge of its present ruined state. The fetishist longs for a mitigated path, for reality and myth to co-exist in small, digestible doses.

For the women of rue Lepic, it is as though they have been brusquely presented with a representation. Their encounter is with that illusory apprehension of Paris that Steele sees as key to its leading role in the fashion industry. From this perspective, Paris is innovative and forward-looking, and the Liberation sees it rise "from the ashes of war, because it still represented the height of luxury, chic and feminine beauty" (Steele 274 - our emphasis). While this myth is perhaps more in accordance with the stall-holders' desires - it is a positive one as opposed to the myth of ruined foundations - it is one that needs to be tempered with reality; it is not tenable for such a myth to walk brazenly into the streets as an answer to all Parisians' prayers.

Given the imposing intertextual implications of "À une passante," it is mete to consider Baudelaire's own theorization of fashion. He frames it in terms of an aspiration on the part of the people in the street, and as such, a force working antagonistically to the satanic pull of the crowd exerted on the flâneur.16 In this way, it corresponds to his search for what David Frisby terms elusive modernity. It seems that the movement towards the poetic effected - in this aspiration - by the Parisian masses provides a fleeting glimpse of the Ideal; the role of crystallizing this falls to the artist. As Frisby notes, "[i]n fact, fashions retain 'the moral and aesthetic feeling of their time." Again, the artist's task is "to extract from fashion whatever element it may contain of poetry within history, to distil the eternal from the transitory" (18). The action of the artist is thus to work again on the Ideal, 
this time as object, made real by fashion. The stall-holders of rue Lepic are less concerned with placing the Ideal in freeze frame; their emphasis seems to be to extract from fashion whatever element it may contain of poetry within history. That is to say, the fleeting intertextual trace is, through the physicality of their actions, consigned (pulled down rather than up) in the annals of history.

The double movement involved in bringing together the eternal and the transitory is a form of deconstructionist critical reading, whereby a literary work expresses its eternalness through the always-already-ness of its reconstruction as text, with each individual instance of text constituting nonetheless an historical moment (of reading). As such, according to Barthes, each new instance would be an expression of the text's primary difference: that which differentiates it from itself.17 What is striking here is just how regularly "À une passante" recurs in the immediate post-Occupation period. In each case, it is as if we are reading the same text repeated. The same reading praxis also applies to historical analysis. As Buck-Morss (116) reminds us, "[a]s a historian Benjamin valued textual exactness not in order to achieve a hermeneutical understanding of the past 'as it actually was' [...] but for the shock of historical citations ripped out of their original context with a 'strong, seemingly brutal grasp,' and brought into the most immediate present." Benjamin's dialectical images, then, inasmuch as they constitute "a repetition of the same," function as much at the interface of the literary and the historical as they do at that of the past and the present.

The idea that reading is a critical engagement and an active rewriting of a literary work reinserts a certain violence at the heart of the loiterly approach that is so often attributed to the flâneur.18 Indeed, the flâneur of the prose poems is engaged by virtue of his participation in the text; his activity is certainly a far cry from the "detached and aimless strolling" that Janet Wolff ascribes to him.19 As such, he embodies not only the trauma of modernity but also the problematic relationship of the artist to the city, which for Rechniewski, lies at the heart of modernism.20 The very nature of his abstraction, as for the literary work itself, provides for his re-contextualization. If the function of the stallholders can be likened to that of the flâneur, it is precisely because of the paradoxical nature of their analysis. The violent prosification that they effect on rue Lepic uproots a famous poem 
but also replaces it into history, which is a flagrant contradiction of the warning offered by Priscilla Parkhurst Ferguson (22), for whom "[i]solating the flâneur from the time, the place and the texts in and from which this urban personage emerged turns the figure into an analytical category that, by definition, lies outside history."21

The move from modernity to modernism can be expressed by a change of perspective, which sees the poet move down from his garret into the city streets. The conflation of the roles of reader and writer, so famously theorized in the wake of the death of the author, has its echoes in the shift in Baudelaire's poetry from verse form to prose poetry, when suddenly the poetnarrator looks at Paris directly, seeing it as it is presented to him just as it is to the reader. And, of course, the prose poems present the position of the reader alongside (or juxtaposed with) the poetic representation of verse motifs. The urban relations implied in understanding Paris as prose poem can be seen to express a textuality of a poststructuralist kind: abstract Meaning confronts real instances of meaning, and the omniscient authorial perspective (Paris seen from a hot-air balloon) is always already actualized as a "haunting" of existential Paris as read by the reader (at street level, where no view of an overarching system of meaning is possible). This is a powerful form of engagement where meaning-making depends on the keenest interaction between the reader and the work of literature, and where the creation of new meaning does nothing to change the original work but, on the contrary, can only happen against the framework of its stability.

If modernity and modernism can be conflated, it is precisely because in the same way that the former theorizes and performs a continuity (albeit an imperfect and/or fragmented one) between the present and the past, the latter maintains this precarious balance between the work and its virtual avatar, the text, with the one ghosting the other. The myth of poststructuralism (and/or postmodernism) is that the dissolution of essential forms of Identity into any number of multiple, relative identities leads to the destruction of the former by the latter.22 Destruction of this critical kind always implies creativity, and it is in this sense that a positive spin can be given to the actions of the stall-holders of rue Lepic: to divest, in this case, is to fashion historical reality as writerly text.23 
For Wolff the stranger is closely related to the flâneur, and his heroism in the modern city lies in the way that he moves freely, avoiding any interaction with others (2004 7). According to our analysis, the flâneur's movements prefigure the struggle of the existentialist hero. The plight of the citizen in the modern city, like the narrator-reader in a prose poem, is continually to encounter its ghosts without being able to communicate with them. Other people and abstract values are on every street corner; there is no escaping them, and interaction with them, whilst inevitable, is also destined to fail. This is a fair description of Jean-Paul Sartre's facticity: engagement, though futile, is the only 'free', and thus heroic, response to situatedness. In this light, the dialogue of "L'Étranger" is an excellent metaphor for Sartre's être pour-soi, whose intentional consciousness continuously reaches beyond the parameters of self but is always already recaptured by the body. In short, both the stranger and the being for-itself exemplify the impossibility of self-coincidence and the inevitability of interaction with the Other.

At the same time as Existentialism is taking Paris by storm, a fashion craze about to be overshadowed (and, indeed, replaced after a relatively short reign) by the New Look, another literary instance of a woman passing by greets the reader's eyes. The text in question is Boris Vian's novel L'Écume des jours, which is published in the same year that Dior's model is attacked:

Des magasins égayaient l'aspect cruel des grands immeubles. Un étalage de fournitures pour fakirs retint l'attention de Colin. II nota la hausse des prix du verre en salade et des clous à rembourrer, par rapport à la semaine passée. [...] Des amoureux s'embrassaient sous un porche. [...] II ferma les yeux et se mit à courir...

II les rouvrit très vite, car il voyait sous ses paupières, des tas de filles et ça lui faisait perdre son chemin. II y en avait une devant lui. Elle allait dans la même direction. On voyait ses jolies jambes dans ses bottillons de mouton blanc, son manteau de peau de pandour décatie et sa toque assortie. Des cheveux roux 
sous sa toque. Son manteau lui faisait des épaules larges et dansait autour d'elle.

— Je veux la dépasser... je veux voir sa figure.

Il la dépassa et se mit à pleurer. Elle comptait au moins cinquante-neuf ans. (48-49)

The context of L'Écume des jours's publication in post-Liberation Paris is such that the allegorical significance of this scene is axiomatic: it offers a caricature of a city in the aftermath of destruction, to which the protagonist is only too keen to turn a blind eye. Of greater interest here, however, is its prose-poetic value, its place at the intersection of text and history.24

Given Colin's gender, and his overtly gendered portrayal in the novel, the scene can be mapped much more directly onto the dynamics of flânerie. The lifting and posing of veils, for example, is far less problematic, since it corresponds to Benjamin's comment that "[t]he crowd was the veil from behind which the familiar city as phantasmagoria beckoned to the flâneur" (Marder 134). As he walks down the street his attention is drawn to a display of supplies for fakirs, after which images of rubble cede to couples kissing in doorways. A veil is thus lifted which allows him access to Baudelaire's Urtext. His pursuit of the woman passing by is destroyed, however, by a revelation that is just as fatal as Baudelaire's fleeting beauty. Colin's need to disavow this 'truth' results in a screen memory composed of the woman's legs, to which his attention is first drawn. Having lifted the veil of the crowd and contemplated the phantasmagoric city, Colin immediately pulls up a veil of his own.

It is easy to suggest that Vian's novel and the incident of rue Lepic share an intertextual space in which "À une passante" functions as a hypotext or, to use Riffaterre's terms, an obligatory intertext. This intertextual reading is only enriched by observations made by Nancy Mitford at the time of the New Look's launch:

The New Look seemed retrogressive in both its status-conferring elegance, and 
its ability to turn women into delicate creatures, teetering on spindly heels. As Mitford remarked though, this constructed image could be 'bliss'; enabling a dramatic return to the spectacular after the desolation of the war years, encouraging the return of the couturier's power to engross women in a fantasy of richness that evoked earlier, less desperate periods. (Arnold 6)

Certainly, the bliss towards which Vian's woman passing by appears to be heading proves quickly to be a fantasy of riches. 25

In Vian's novel, fashion functions as a catalytic agent and a response to public sentiment.26 L'Écume des jours also follows literary fashion, offering, amongst numerous others, a parody of the noir fiction that emerges in Paris post-Occupation. One roman noir not of Marcel Duhamel's stable contains a passage showcasing another instance of fleeting beauty. The following extract is taken from Léo Malet's Nestor Burma contre CQFD (1945):

Elle surgissait du couloir à soixante centimètres duquel je me tenais immobile. J'étais trop contre le mur pour que semblable mésaventure ne m'arrivât pas si quelqu'un faisait précipitamment irruption de l'immeuble. Or, la jeune fille en était sortie littéralement en trombe. Je n'avais jamais vu quelqu'un d'aussi pressé ! Elle allait rapidement, au rythme souple de ses jambes fines et élégantes, merveilleusement gainées d'une soie rare pour l'époque. Ses souliers à hauts talons ne faisaient aucun bruit. Elle portait un tailleur bleu par-dessous une veste de fourrure. Ses cheveux auburn se confondaient avec la couleur du mouton doré. J'avais seulement entr'aperçu son visage. II ne m'avait pas paru vilain du tout. En tout cas, l'ensemble que je voyais s'éloigner était 
plein de grâce. Cependant, la surprise passée, je hâtais le pas à mon tour. [...] J'avais rattrapé la jeune fille pressée et j'étais sur ses talons, lorsqu'une véritable pluie d'éclats s'abattit sur le boulevard. [...] Comme piquée par un serpent, elle se retourna brusquement. Je me mis à rire. [...] Elle haussa les épaules et reprit sa marche. Elle devait avoir vingt, vingt et un ans. Vraiment jolie. (126-27)

Again modernity takes the form of a woman passing by.

If we return to Covin's analytic truth, which states that because prose poetry equals Paris then Paris equals prose poetry, we can propose in the same vein that because Paris equals modernity then the modernity of any metropolis will always somehow remind us of Paris. And finally, if modernity is a woman passing by then a woman passing by will always remind us of a particular Baudelairean model of modernity. It is as if we are hard-wired to see in every woman passing by the festoon and hem of Baudelaire's passante. 27

By removing the crowd from the street of his poem - as Benjamin notes, "the crowd is nowhere named in either word or phrase" (1997 124) — and lifting the veil that we may gaze directly onto the phantasmagoric city, Baudelaire places readers in the position of the soon-to-be-traumatized. For intertextuality to be productively employed here, however, it is clearly not sufficient to talk in vague terms of a surprising nexus of texts all apparently drawing their inspiration from a common source. If we trace our intertext back to its source we are obliged consider the foundational nature of "À une passante." Baudelaire's poem sends the clad figure back to the crowd and establishes the clothes of the woman passing by as a fetish, as it turns her appearance on the street into a myth of modernity. Festoons and hems are now enough - they both veil and symbolize the shock of the double city - and Malet, Vian and the stall-holders of rue Lepic all dwell on the "sartorial representation." And that representation is still with us today. 
1 For David Kunzle the particularly marked global political ambivalence of the post-war period is a direct contributor to a new sartorial fetishism. He describes the New Look as being "both strong and delicate, a masculine/feminine conjunction epitomized in the wasp-waisted, femininely tailored suit" (223).

2 Ross Chambers uses this concept of haunting to introduce the belated stance whereby the critical subject must always take the time to be out of step.

3 Life in the modern city, according to Wilson, "ceases to form itself into epic or narrative, becoming instead a short story, dreamlike, insubstantial or ambiguous" ("Invisible," 79).

4 Chris Jenks for one believes that, as a product of modernity, the flâneur "provides one image of how [that] state of being in time can be realised" (30).

5 Keith Tester and Elizabeth Rechniewski also consider news of the flâneur's death to have been greatly exaggerated; both trace his presence in such twentieth-century texts as JeanPaul Sartre's La Nausée (Tester 1-21; Rechniewski passim).

6 For Shields, he is Parisian by virtue of being "always as much mythic as [...] actual" (62-63).

7 This reading draws on the chiastic form of the full title, in which Les Petits poèmes en prose is opposed to the sub-title Le Spleen de Paris. According to Covin, whilst spleen can be seen to oppose Paris, just as poem opposes prose, in which case the city is re-presented as an Ideal, Paris can also be seen to stand outside the opposition, encompassing the tension between the poles.

8 For Robert Jauß, fashion corresponds almost exactly to the paradox of prose poetic Paris: "It embodies the poetical in the historical, the eternal within transitoriness. Beauty steps forth in fashion, not as a well-worn, timeless ideal but as the idea that man forms for himself of beauty, an idea that reveals the mores and aesthetics of his time and that allows man to get closer to what he aspires to be" (quoted in Lehmann 226). 
9 So much of France's cinematographic and literary output lends itself to allegorical interpretation. Kristin Ross's study testifies to the prominence of this tendency in the 1950s and '60s.

10 For his part, David Harvey rejects the myth that modernity "constitutes a radical break with the past" (1). See also Ellen Lee McCallum's excellent essay on fetishism, and especially her introduction, which develops this idea of the juncture of knowledge and desire.

11 We might think of the paradoxical tension of the modernist text, which simultaneously pulls its reader into its narrative by revealing itself as text. This reflexivity is an erotic act: it is by pushing the reader away (by stopping her from losing herself passively in the text) that the story compels her to produce it as text.

12 We should point out that we are not suggesting that the period between the writing of Les Petits poèmes en prose and the Second World War represented one hundred years devoid of fascination with, and famous acts of violence exacted upon, women passing by. We might think of the "well-dressed woman in the Rue Blanche" (Harvey 328) who happened to pass by the bourgeois diarist Audéod and was denounced by him and summarily shot in the back because she was carrying two bottles (this incident was set against the backdrop of the Paris Commune of 1871 and the myth of la Pétroleuse).

13 In critical terms, what makes flânerie pleasurable, after all, is its combination of jouissance (abandonment to the pull of the crowd) and plaisir (action, in the form of applied or writerly voyeurism).

14 "For Benjamin, these two elements can never be understood as discrete entities - each element exists only in relation to the other" (Marder 130-131).

15 According to Benjamin's reading, "[t]he invisible but overpowering presence of the ruins of Troy in the poem shatters the newly built city of Paris at the level of its mythic foundation. The image of the modern city is superimposed on the rubble of the ancient one - thus the modernity of the new city must be 
read through the figure of its past and future decrepitude" (Marder 131-132).

16 It is referred to, for example, as "a symptom of the taste for the ideal which floats on the surface of all the crude, terrestrial and loathsome bric-a-brac that the natural life accumulates in the human brain" (quoted in Frisby 18).

17 In this way, readers who do not take the time to reread are destined to read the same text everywhere (hence Chambers's call for readers to be loiterly). This aspect of Barthes's work is commented on interestingly by Barbara Johnson (175).

18 There is a hint of the rapprochement of flânerie and deconstruction in Wilson: "The repetitive monotony of the flâneur's regime of strolling is an instance of 'eternal recurrence' - the eternal recurrence of the new, which is 'always ever the same"' (2004 80).

19 We follow Wolff in our use the masculine pronoun. The quote is taken from the 'Gender and Flânerie' section of her chapter in Tester's collection (Wolff 1994 125).

20 Rechniewski describes a textual identity: "[H]e continually re-emerges in new guises and contexts" because "his stance is continually called forth by the fractured cultural field" (98).

21 Notwithstanding her own warning, Ferguson draws a strong connection between the repeated appearances of the flâneur and periods of change in the history of Paris.

22 The allusion here is to Harvey's rebuttal of the myth of modernity. He goes on to posit that "[m]odernity is always about "creative destruction"' (1). In order to give the lie to this myth he gives Haussmann as an example of a creator-destructor who seeks in his memoirs to understate his debt to his predecessors and those of his contemporaries who advised him.

23 In the same way, the vocabulary of Barthes's Pleasure of the Text is clearly visible in Ferguson's description of women's role in the dynamics of the urban gaze: "A woman idling 
on the street is to be 'consumed' and 'enjoyed' along with the rest of the sights that the city affords" (28).

24 We have elsewhere discussed this scene from the perspective of the erection of a fetish, which comes into play almost immediately hereafter (two pages later in the novel) when the protagonist Colin is drawn by the legs of two women, on which he is fixated, up a flight of stairs to a party where the novel plunges from surrealistic possibility to tragic reality and, ultimately, entropy (Rolls, 2004, 2005).

25 An understanding of the importance of the New Look's release in Paris can also shed new light on one of the most famous scenes of L'Écume des jours, in which Jean-Paul Sartre's famous and well-attended lecture "L'Existentialism est un humanisme", given at Club Maintenant in Paris on 29 October 1945 , is grossly parodied to the point where 'Jean-Sol Partre' has to cut his way to the stage with an axe. This scene in fact bears an uncanny resemblance to descriptions of Dior's presentation of his first collection at 30 avenue Montaigne on 12 February 1947: "No attempt had been made to drum up publicity; but Dior had powerful friends [...] All had recognized Dior, from his work at Lelong, as a great designer of prodigious talent. This has stirred up a great deal of excitement and curiosity about Dior's new fashion house. The crush was so great that some people even attempted to get in through the top of the house with ladders" (Beevor and Cooper 313).

26 As Kunzle so neatly captures the scene, "even before the end of the war, soon after the liberation of Paris in August 1944, rumours began to circulate of a wasp-waist revival" (221).

27 This offers us an insight into the poet's modernism, which, if we think back to Modernism 1010 and such classics as André Gide's L'Immoraliste, involves implicating the reader in the development and outcomes of the text. 


\section{WORKS CITED}

Agulhon, Maurice and Pierre Bonte. Marianne. Les Visages de la République. Paris: Gallimard, 1992.

Arnold, Rebecca. Fashion, Desire and Anxiety: Image and Morality in the $20^{\text {th }}$ Century. New Brunswick, NJ: Rutgers UP, 2001.

Baudelaire, Charles. "À une passante." Les Fleurs du mal. Paris: Calmann-Lévy, 1868.

---. "L'Étranger." Petits Poëmes en prose (Le Spleen de Paris). Le Jeune enchanteur. Paris: Louis Conard, 1926.

Beevor, Antony and Artemis Cooper. Paris after the Liberation: 1944-1949. London: Penguin, 1995.

Bell, Quentin. On Human Finery. London: Hogarth Press, 1947.

Benjamin, Walter. Charles Baudelaire: A Lyric Poet in the Era of High Capitalism. Trans. Harry Zohn. London and New York: Verso, 1997.

---. The Arcades Project. Trans. Howard Eiland and Kevin McLaughlin. Cambridge, MA and London: The Belknap Press of Harvard UP, 1999.

Buck-Morss, Susan. "The Flâneur, the Sandwichman and the Whore." Urban Culture: Critical Concepts in Literary and Cultural Studies. Ed. Chris Jenks. London and New York: Routledge, 2004. 2:115-48.

Chambers, Ross. Loiterature. Lincoln; London: U of Nebraska P, 1999.

Covin, Michel. L'Homme de la rue: Essai sur la poétique baudelairienne. Paris: L'Harmattan, 2000.

Ferguson, Priscilla Parkhurst. "The Flâneur on and off the Streets of Paris." The Flâneur. Ed. Keith Tester. London and New York: Routledge, 1994. 22-42. 
Forbes, Jill and Michael Kelly, eds. French Cultural Studies: An Introduction. Oxford: Clarendon Press, 1995.

Frank, Robert. "La mémoire empoisonnée." La France des années noires 2 : De l'occupation à la liberation. Eds. JeanPierre Azéma and François Bédarida. Paris: Éditions du Seuil, 2000. 541-76.

Frisby, David. Fragments of Modernity: Theories of Modernity in the Work of Simmel, Kracauer and Benjamin. Cambridge, Massachusetts: The MIT Press, 1986.

Gamman, Lorraine and Merja Makinen. Female Fetishism. New York: NYU Press, 1994.

Harvey, David. Paris, Capital of Modernity. New York and London: Routledge, 2003.

Higonnet, Patrice. Paris, capitale du monde: Des Lumières au surréalisme. Paris: Tallandier, 2006.

Horne, Alistair. Seven Ages of Paris. New York: Alfred A. Knopf, 2003.

Jenks, Chris. "Watching your Step: The History and Practice of the Flâneur." Urban Culture: Critical Concepts in Literary and Cultural Studies. Ed. Chris Jenks. London and New York: Routledge, 2004. 2:26-43.

Johnson, Barbara. "The Critical Difference." Critical Essays on Roland Barthes. Ed. Diana Knight. New York: G.K. Hall, 2000. 174-82.

Kunzle, David. Fashion and Fetishism: Corsets, Tight-Lacing and Other Forms of Body-Sculpture. Stroud, Gloucestershire: Sutton, 2004.

Lehmann, Ulrich. Tigersprung: Fashion in Modernity. Cambridge, MA and London: The MIT Press, 2000.

Lee McCallum, Ellen. Object Lessons: How to do Things with Fetishism. New York: SUNY Press, 1999. 
Malet, Léo. Les Enquêtes de Nestor Burma et les nouveaux mystères de Paris. Euvres completes, tome 1. Paris: Robert Laffont, 1985.

Marder, Elissa. "Flat Death: Snapshots of History." Diacritics 22:3-4 (1992): 128-44.

Rechniewski, Elizabeth. "When and Why did the Flâneur Die? A Modern Detective Story." Literature and Aesthetics: The Journal of the Sydney Society of Literature and Aesthetics 17.2 (2007): 90-103.

Rémond, René. "Des lendemains qui chantent ?" La France des années noires 2 : De l'occupation à la liberation. Eds. JeanPierre Azéma and François Bédarida. Paris: Éditions du Seuil, 2000. 523-40.

Riffaterre, Michel. "La Trace de l'intertexte." La Pensée 215 (1980): 4-18.

Rolls, Alistair. "In Olden Days a Glimpse of Stocking': Fashion, Fetishism and Modernity in Boris Vian's L'Écume des jours." French Cultural Studies 15:2 (2004): 99-113.

---. "Throwing Caution to the French Wind: Peter Cheyney's Success Overseas in 1945." Australian Journal of French Studies 43:1 (2006): 35-47.

---. "Silk or Nylon: Boris Vian, Leg Fetishism and the American Way." AUMLA: Journal of the Australasian Universities Language and Literature Association 103 (2005): 93-108.

Ross, Kristin. Fast Cars, Clean Bodies: Decolonization and the Reordering of French Culture. Cambridge, MA and London: The MIT Press, 1996.

Shields, Rob. "Fancy Footwork: Walter Benjamin's Notes on Flânerie." The Flâneur. Ed. Keith Tester. London and New York: Routledge, 1994. 61-80.

Simmel, Georg. "Fashion." The American Journal of Sociology 6 (1957): 541-58. 
Steele, Valerie. Paris Fashion: A Cultural History. Oxford; New York: Berg, 1998.

Tester, Keith, ed. "Introduction." The Flâneur. London; New York: Routledge, 1994. 1-21.

Veillon, Dominique. Fashion under the Occupation. Trans. Miriam Kochan. Oxford; New York: Berg, 2002.

Vian, Boris. Fuvres complètes. Tome deuxième. Paris: Fayard, 1999.

Wilson, Elizabeth. The Contradictions of Culture: Cities, Culture, Women. London; Thousand Oaks, California and New Delhi: SAGE, 2001.

---. "The Invisible Flâneur." Urban Culture: Critical Concepts in Literary and Cultural Studies. Ed. Chris Jenks. London and New York: Routledge, 2004. 2:63-85.

Wolff, Janet. "The Artist and the Flâneur," In The Flâneur. Ed. Keith Tester. London and New York: Routledge, 1994. 11137.

---. "The Invisible Flâneuse: Women and the Literature of Modernity" Urban Culture: Critical Concepts in Literary and Cultural Studies. Ed. Chris Jenks. London and New York: Routledge, 2004. 2:3-16. 